\title{
Selective Cholinesterase Inhibitory Activities of a New Monoterpene Diglycoside and Other Constituents from Nelumbo nucifera Stamens
}

\author{
Hyun Ah Jung,${ }^{a}$ Yu Jung Jung, ${ }^{a}$ Sook Kyung Hyun,,${ }^{a}$ Byung-Sun Min,,${ }^{b}$ Dong-Wook KIM, ${ }^{c}$ \\ Jee H. JunG, ${ }^{d}$ and Jae Sue $\mathrm{CHOI}^{*, a, e}$ \\ ${ }^{a}$ Division of Food Science and Biotechnology, Pukyong National University; Busan 608-737, Republic of Korea: ${ }^{b}$ College \\ of Pharmacy, Catholic University of Daegu; Gyeongbuk 712-702, Republic of Korea: ${ }^{\circ}$ Division of Applied Bioscience, \\ Mokpo National University; 61 Chonggkye-myeon, Muan-gun, Jeonnam 534-792, Republic of Korea: ${ }^{d}$ College of \\ Pharmacy, Pusan National University; Busan 609-735, Republic of Korea: and e Blue-Bio Industry RIC; 995 \\ Eomgwangno Busanjin-gu, Busan 614-714, Republic of Korea. Received July 17, 2009; accepted October 22, 2009
}

A new $\beta$-cyclogeraniol diglycoside (5), along with four known components, cycloartenol (1), $p$-hydroxybenzoic acid (2), vanilloloside (3), and $5^{\prime}-O$-methyladenosine (4), were first isolated from the $n$-BuOH fraction of Nelumbo nucifera stamens. The chemical structure of 5 was elucidated as 1-hydroxymethyl-2,6,6-trimethyl-1-cyclohexene 9- $O$ - $\beta$-D-glucopyranosyl-( $1 \rightarrow 6)-\beta$-D-glucopyranoside (nuciferoside) on the basis of chemical and spectroscopic evidence, including 1D, 2D NMR, and MS. The anti-Alzheimer effects of $1-5$ were evaluated via the acetylcholinesterase $(\mathrm{AChE})$, butyrylcholinesterase $(\mathrm{BChE})$, and $\beta$-site amyloid precursor protein (APP) cleaving enzyme 1 (BACE1) inhibition assays. Compounds $1-3$ and 5 showed good and noncompetitive inhibition against $\mathrm{AChE}$ with $\mathrm{IC}_{50}$ values of $11.89,20.07,4.55$, and $3.20 \mu_{\mathrm{M}}$ and $K_{\mathrm{i}}$ values of $15.71,25.44,7.76$, and 5.76 $\mu_{\mathrm{M}}$, respectively. Compounds 1,2 , and 5 also possessed $\mathrm{BChE}$ inhibitory activities with $\mathrm{IC}_{50}$ values of 13.93, 62.29, 205.78, and 83.06 $\mu \mathrm{M}$, respectively. The selectivity index (SI) values of $1,2,3$, and 5, calculated from $\mathrm{IC}_{50}$ values of $\mathrm{BChE}$ and $\mathrm{AChE}$, were 1.2, 3.1, 45.7, and 26.0. However, all isolated compounds lacked BACE1 inhibition up to $100 \mu_{\mathrm{M}}$ Therefore, $N$. nucifera stamens-derived compounds could potentially exert their primary anti-Alzheimer effects as $\mathrm{AChE}$ inhibitors rather than BACE1 inhibitors.

Key words Nelumbo nucifera; $\beta$-cyclogeraniol diglycoside; nuciferoside; cholinesterase inhibition; kinetic parameter

Nelumbo nucifera GaERTN., the family of Nelumbonaceae, is a perennial, rhizomatous, aquatic plant distributed throughout Asia, including India, China, and Egypt. The plant is comprised of: membranous, peltate, orbicular, and concave leaves; nut-contained and ovoid fruits; black, hard, and ovoid seeds; nodal roots. In Korea, China and India, various parts of $N$. nucifera have been used in foodstuffs and traditional medicine for the treatment of diarrhea, gastritis, insomnia, nervous prostration and as a haemostatic. ${ }^{1-3)}$ In particular, numerous biological activities, including antioxidant, ${ }^{4,5)}$ anti-human immunodeficiency virus (HIV), ${ }^{6}$ antihyperlipidemic, ${ }^{1)}$ hepatoprotective, and antiobesity effects ${ }^{7-9)}$ have been reported from the leaves of $N$. nucifera. In addition, Mukherjee et al. reported that N. nucifera rhizomes possessed diverse bioactivities, including antibacterial, ${ }^{10)}$ antidiarrhoeal, ${ }^{11)}$ diuretic, ${ }^{12)}$ antifungal,${ }^{13)}$ antipyretic, ${ }^{14)}$ anti-inflammatory, ${ }^{15)}$ and antidiabetic. ${ }^{16,17)}$ Additionally, the rhizomes have been reported to exhibit antihypertensive ${ }^{18)}$ and memory enhancing activities. ${ }^{19)}$ Regarding the seeds, several reports exist on their hepatoprotective ${ }^{20)}$ antioxidant, ${ }^{21)}$ antifertility ${ }^{22)}$ and antipyretic activities, ${ }^{23)}$ as well as their inhibitory effects on pulmonary fibrosis. ${ }^{24)}$ Recently, N. nucifera semen extract was reported to improve memory in rats with scopolamine-induced dementia through the induction of choline acetyltransferase expression and inhibition of acetylcholinesterase (AChE) ${ }^{25}$ ) Even though individual parts of this plant have been the target of distinct biological and pharmacological research, there are limited studies of the stamens, with the exception of research focusing upon the antioxidant and rat lens aldose reductase (RLAR) inhibition ${ }^{26-28)}$ and anti-allergic activities ${ }^{29)}$ attributed to the flavonoids.

Alzheimer's disease (AD) is a neurodegenerative disease and the most frequent and predominant cause of dementia in the elderly, provoking progressive cognitive decline, psychobehavior disturbances, memory loss, the presence of senile plaques, neurofibrillary tangles, and a decrease in cholinergic transmission. ${ }^{30,31)}$ Although the pathogenesis of AD is complicated and involved in numerous pathways, two major hypotheses are currently under consideration regarding the molecular mechanism, the cholinergic hypothesis and the amyloid cascade hypothesis. Thus, the focus herein is upon inhibitors of select cholinesterases (ChEs) to alleviate cholinergic deficits and improve neurotransmission and $\beta$-site amyloid precursor protein (APP) cleaving enzyme 1 (BACE1; aspartyl protease, $\beta$-secretase, and memapsin 2 ) inhibitors to preclude formation and accumulation of amyloid $\beta$ peptide (A $\beta$ ). Pursuant to this, both could then be established as viable therapeutic targets for $\mathrm{AD}^{31-34)}$

Given that numerous promising pharmaceuticals and nutraceuticals are constantly isolated from effective natural products, and that a previous study from this lab indicated potent antioxidant and RLAR inhibitory activities of $N$. nucifera stamens, this plant was chosen for ongoing investigations into anti-AD activities. The present work deals with the isolation and characterization of a new $\beta$-cyclogeraniol diglycoside (5), and four known compounds: cycloartenol (1); $p$-hydroxybenzoic acid (2); vanilloloside (3); 5'-Omethyladenosine (4). Furthermore, the inhibitory activities of 1-5 toward ChEs, including AChE and butyrylcholinesterase (BChE), and BACE1 were evaluated.

\section{MATERIALS AND METHODS}

General Experimental Procedures Optical rotation was determined on a Perkin-Elmer 341 MC polarimeter (Norwalk, CT, U.S.A.). The ${ }^{1} \mathrm{H}$ - and ${ }^{13} \mathrm{C}-\mathrm{NMR}$, and distor- 
tionless enhancement by polarization transfer (DEPT) spectra were determined using a JEOL JNM ECP-400 spectrometer (Tokyo, Japan) at $400 \mathrm{MHz}$ for ${ }^{1} \mathrm{H}$ and $100 \mathrm{MHz}$ for ${ }^{13} \mathrm{C}$. The chemical shifts were referenced to residual solvent peaks $\left(\mathrm{CDCl}_{3}, \mathrm{DMSO}-d_{6}\right.$, and pyridine- $\left.d_{5}\right)$. The EI-MS data were collected on a GC-MS QP-5050A spectrometer (Shimadzu, Kyoto, Japan). The LR and HR FAB-MS data were assessed using a JEOL JMS-HX110/110A spectrometer (Tokyo, Japan). Column chromatography was conducted using silica ( $\mathrm{Si}$ ) gel 60 (70-230 mesh, Merck, Darmstadt, Germany), RP-18 Lichroprep (40-63 $\mu \mathrm{m}$, Merck, Germany), and Amberlite MB-3 (Sigma Co., St. Louis, MO, U.S.A.). TLC (thin layer chromatography) was conducted on precoated Merck Kieselgel $60 \mathrm{~F}_{254}$ plates $(20 \times 20 \mathrm{~cm}, 0.25 \mathrm{~mm})$ and a RP-18 $\mathrm{F}_{254 \mathrm{~s}}$ plates $(5 \times 10 \mathrm{~cm}$, Merck, Darmstadt, Germany), using $50 \%$ $\mathrm{H}_{2} \mathrm{SO}_{4}$ as a spray reagent.

Chemicals and Reagents Electric-eel AChE (EC 3.1.1.7), horse-serum BChE (EC 3.1.1.8), acetylthiocholine iodide (ACh), butyrylthiocholine chloride (BCh), 5,5'-dithiobis[2nitrobenzoic acid] (DTNB), quercetin, and galanthamine were purchased from Sigma-Aldrich Co. (St. Louis, MO, U.S.A.). BACE1 fluorescence resonance energy transfer (FRET) assay kit ( $\beta$-Secretase) was purchased from the PanVera Co. (Madison, WI, U.S.A.). All chemicals and solvents used were purchased from E. Merck, Fluka, and Sigma \& Aldrich Co., unless stated otherwise.

Plant Materials The stamens of $N$. nucifera were purchased from a local retailer and authenticated by Prof. D. W. Kim at Mokpo National University (Jeonnam Province, Republic of Korea). A voucher specimen (No. 20040420) was deposited in the laboratory of Prof. J. S. Choi.

Extraction, Fractionation, and Isolation The stamens $(3.4 \mathrm{~kg})$ of $N$. nucifera were refluxed in methanol $(\mathrm{MeOH})$ for $3 \mathrm{~h}(91 \times 3)$. The total filtrate was then concentrated to dryness in vacuo at $40{ }^{\circ} \mathrm{C}$ to render the $\mathrm{MeOH}$ extract $(560 \mathrm{~g})$. This extract was suspended in distilled water $\left(\mathrm{H}_{2} \mathrm{O}\right)$ and then successively partitioned between methylene chloride $\left(\mathrm{CH}_{2} \mathrm{Cl}_{2}\right)$, ethyl acetate (EtOAc), and $n$-butanol $(n-\mathrm{BuOH})$, to yield $\mathrm{CH}_{2} \mathrm{Cl}_{2}$ (330 g), EtOAc (20 g), $n$-BuOH (66 g) fractions, respectively, as well as an $\mathrm{H}_{2} \mathrm{O}$ residue $(140 \mathrm{~g})$. A portion of the $n$ - $\mathrm{BuOH}$ fraction $(26.6 \mathrm{~g})$ was first chromatographed over a $\mathrm{Si}$ gel column $(100 \mathrm{~mm}$ i.d. $\times 80 \mathrm{~cm})$, using a mixed solvent system of EtOAc-MeOH $(20: 1 \rightarrow 10: 1 \rightarrow 5: 1 \rightarrow 0: 1$, gradient $)$ to afford thirteen fractions (BF01-BF13). Repeated column chromatography of fraction 1 (BF01, $1.5 \mathrm{~g}$ ) was performed over a Si gel column $(20 \mathrm{~mm}$ i.d. $\times 20 \mathrm{~cm})$ with $n$-hexaneEtOAc $(15: 1 \rightarrow 0: 1$, gradient) to obtain cycloartenol (1, $25 \mathrm{mg}$ ) and $p$-hydroxybenzoic acid (2, $13 \mathrm{mg})$. Repeated column chromatography of combined fractions 2 and 3 (BF02/03, $9 \mathrm{~g})$ was performed over a Si gel column $(60 \mathrm{~mm}$ i.d. $\times 60 \mathrm{~cm})$ with EtOAc- $\mathrm{MeOH}-\mathrm{H}_{2} \mathrm{O}(40: 1: 1)$ yielding twelve fractions (BF02/03-01-BF02/03-12). Fraction 12 (BF02/03-12, $1.5 \mathrm{~g}$ ) was chromatographed over an RP-18 gel column $(20 \mathrm{~mm}$ i.d. $\times 20 \mathrm{~cm})$ with $50 \% \mathrm{MeOH}$, yielding eight fractions (BF02/03-12-1-BF02/03-12-8). Fraction 4 (BF02/ 03-12-4, $300 \mathrm{mg}$ ) was chromatographed over a Si gel column $(20 \mathrm{~mm}$ i.d. $\times 20 \mathrm{~cm})$ with $\mathrm{CH}_{2} \mathrm{Cl}_{2}-\mathrm{MeOH}-\mathrm{H}_{2} \mathrm{O}(65: 35: 10)$ to obtain vanilloloside $(3,12 \mathrm{mg})$ and $5^{\prime}-O$-methyladenosine (4, $15 \mathrm{mg})$. A precipitate of fraction 5 (BF02/03-12-5, $250 \mathrm{mg}$ ) was purified using an HPLC system consisting of a 307 pump (Gilson, F-95400 Villiers Le Bel, France), RI detector

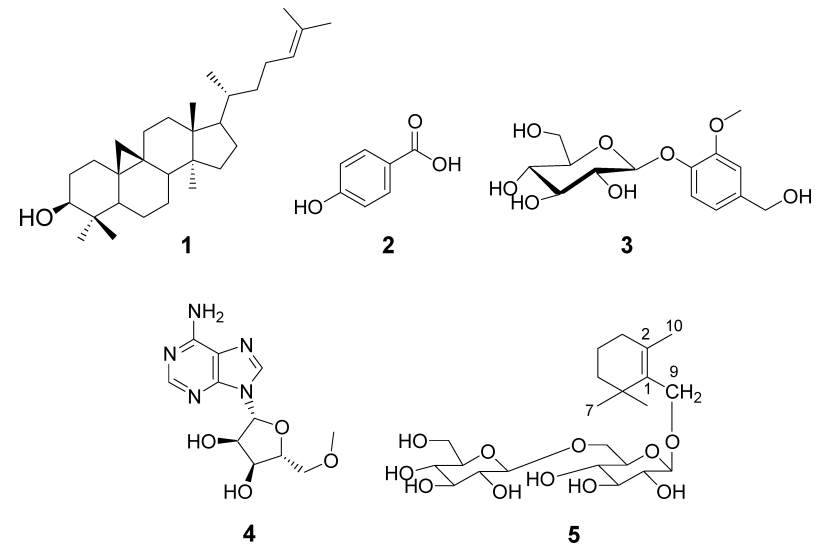

Fig. 1. Structure of Compounds $\mathbf{1}-\mathbf{5}$ from $N$. nucifera Stamens

Table 1. NMR Spectral Data of $\mathbf{5}$ Isolated from N. nucifera Stamens

\begin{tabular}{|c|c|c|}
\hline No. & ${ }^{1} \mathrm{H}$ & ${ }^{13} \mathrm{C}$ \\
\hline 1 & & 134.5 \\
\hline 2 & & 134.3 \\
\hline 3 & $1.81(2 \mathrm{H}, \mathrm{m})$ & 32.9 \\
\hline 4 & $1.47(2 \mathrm{H}, \mathrm{m})$ & 19.6 \\
\hline 5 & $1.34(2 \mathrm{H}, \mathrm{m})$ & 39.6 \\
\hline 6 & & 34.2 \\
\hline 7 & $1.12(3 \mathrm{H}, \mathrm{s})$ & 28.7 \\
\hline 8 & $1.11(3 \mathrm{H}, \mathrm{s})$ & 28.6 \\
\hline 9 & $\begin{array}{l}4.85(1 \mathrm{H}, \mathrm{d}, J=12.5 \mathrm{~Hz}) \\
4.37(1 \mathrm{H}, \mathrm{dd}, J=12.5,5.2 \mathrm{~Hz})\end{array}$ & 70.2 \\
\hline 10 & $1.77(3 \mathrm{H}, \mathrm{s})$ & 20.2 \\
\hline $1^{\prime}$ & $4.75(1 \mathrm{H}, \mathrm{d}, J=7.8 \mathrm{~Hz})$ & 104.4 \\
\hline $2^{\prime}$ & $3.92(1 \mathrm{H}, \mathrm{m})$ & 74.9 \\
\hline $3^{\prime}$ & $4.24(1 \mathrm{H}, \mathrm{m})$ & 78.4 \\
\hline $4^{\prime}$ & $4.24(1 \mathrm{H}, \mathrm{m})$ & 71.6 \\
\hline $5^{\prime}$ & $4.18(1 \mathrm{H}, \mathrm{m})$ & 77.4 \\
\hline $6^{\prime}$ & $\begin{array}{l}4.85(1 \mathrm{H}, \mathrm{m}) \\
4.11(1 \mathrm{H}, \mathrm{m})\end{array}$ & 66.0 \\
\hline $1^{\prime \prime}$ & $5.17(1 \mathrm{H}, \mathrm{d}, J=7.8 \mathrm{~Hz})$ & 105.5 \\
\hline $2^{\prime \prime}$ & $4.05(1 \mathrm{H}, \mathrm{m})$ & 75.2 \\
\hline $3^{\prime \prime}$ & $4.24(1 \mathrm{H}, \mathrm{m})$ & 78.4 \\
\hline $4^{\prime \prime}$ & $4.05(1 \mathrm{H}, \mathrm{m})$ & 71.9 \\
\hline $5^{\prime \prime}$ & $3.92(1 \mathrm{H}, \mathrm{m})$ & 78.4 \\
\hline \multirow[t]{2}{*}{$6^{\prime \prime}$} & $4.52(1 \mathrm{H}, \mathrm{dd}, J=12.3,2.2 \mathrm{~Hz})$ & 62.7 \\
\hline & $4.34(1 \mathrm{H}, \mathrm{dd}, J=12.3,4.9 \mathrm{~Hz})$ & \\
\hline
\end{tabular}

(Shodex RI-101, Showa Denko, Kanagawa, Japan), and a Waters Spherisorb column (Semi-Prep column, $10 \times 250 \mathrm{~mm}$, ODS2) in $70 \% \mathrm{MeOH}$ to obtain the cyclocitral-type monoterpene diglycoside, nuciferoside $(\mathbf{5}, 90 \mathrm{mg})$. The isolated compound (5) was identified by chemical and spectroscopic analysis, including 1D, 2D NMR, and MS; compounds 1 15,36) $^{35,3}$ $2,{ }^{37)} 3,{ }^{38)}$ and $4^{39}$ were characterized by comparison with published data (Fig. 1).

Nuciferoside (5) White amorphous powder; $[\alpha]_{\mathrm{D}}^{20}-40^{\circ}$ $(c=0.4, \mathrm{MeOH})$; EI-MS $m / z$ (\%, relative intensity): 478 $\left[\mathrm{C}_{22} \mathrm{H}_{38} \mathrm{O}_{11}\right]^{+}(0.16), 316[\mathrm{M}-\mathrm{Glc}]^{+}(0.16), 154$ [M-Glc$\mathrm{Glc}^{+}{ }^{+}$(32.6), $136\left[\mathrm{M}-\mathrm{Glc}-\mathrm{Glc}-\mathrm{H}_{2} \mathrm{O}\right]^{+}$(36.7); positive LR FAB-MS $m / z$ : $501.2[\mathrm{M}+\mathrm{Na}]^{+}$; negative LR FAB-MS $m / z$ : $477.25[\mathrm{M}-\mathrm{H}]^{-}$; HR FAB-MS $m / z$ : 501.2308 (Calcd for $\left.\mathrm{C}_{22} \mathrm{H}_{38} \mathrm{O}_{11} \mathrm{Na}: 501.2336\right)$; ${ }^{1} \mathrm{H}-\mathrm{NMR}\left(400 \mathrm{MHz}\right.$, pyridine- $d_{5}$ ) $\delta$ : given in Table $1 ;{ }^{13} \mathrm{C}-\mathrm{NMR}\left(100 \mathrm{MHz}\right.$, pyridine- $\left.d_{5}\right) \delta$ : given in Table 1.

Determination of Sugar in 5 Compound 5 was refluxed with $2 \mathrm{~N} \mathrm{HCl} /$ dioxane $(1: 1,2 \mathrm{ml})$ for $2 \mathrm{~h}$. The mixture was 
extracted with EtOAc $(5 \mathrm{ml} \times 3$ times $)$. The residual water layer was neutralized with Amberlite MB-3 and dried to obtain a residue. The residue was dissolved in pyridine $(1 \mathrm{ml})$, and $0.1 \mathrm{M} \mathrm{L}$-cysteine methyl ester hydrochloride in pyridine $(2 \mathrm{ml})$ was added. The mixture was maintained at $60{ }^{\circ} \mathrm{C}$ for $1.5 \mathrm{~h}$. After drying the reaction mixture in vacuo, the residue was trimethylsilylated with hexamethyldisilazane-trimethylchlorosilane $(0.1 \mathrm{ml})$ at $60^{\circ} \mathrm{C}$ for $1 \mathrm{~h}$. The mixture was partitioned between hexane and $\mathrm{H}_{2} \mathrm{O}(0.3 \mathrm{ml}$ each), and the hexane extract was analyzed by GC (column, DB-1, $0.25 \mathrm{~mm}$ i.d. $\times 30 \mathrm{~m}$; column temperature, $50-230^{\circ} \mathrm{C}$, $15^{\circ} \mathrm{C} / \mathrm{min}, 230^{\circ} \mathrm{C}$ for $18 \mathrm{~min}$; carrier gas, He). The sugar derivatives obtained exhibited a retention time of $21.30 \mathrm{~min}$, identified with that of authentic D-glucose. Under these conditions, a derivative of L-glucose displayed a retention time of $22.00 \mathrm{~min}^{40)}$

In Vitro ChEs Enzyme Assay The inhibitory activities of the ChEs were measured using the spectrophotometric method developed by Ellman et al. ${ }^{41)} \mathrm{ACh}$ and $\mathrm{BCh}$ were used as the substrates to assay the inhibitions of AChE and $\mathrm{BChE}$, respectively. The reaction mixture contained: $140 \mu \mathrm{l}$

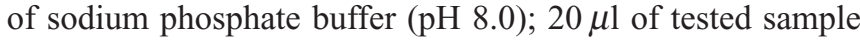
solution (final concentration (f.c.) $100 \mu \mathrm{M}$ for the compounds); and $20 \mu \mathrm{l}$ of either AChE or BChE solution, which were mixed and incubated for $15 \mathrm{~min}$ at room temperature. All tested samples and the positive control (galanthamine) were dissolved in $10 \%$ analytical grade dimethyl sulfoxide (DMSO). The reactions were started with the addition of $10 \mu \mathrm{l}$ of DTNB and $10 \mu \mathrm{l}$ of either ACh or BCh, respectively. The hydrolysis of $\mathrm{ACh}$ or $\mathrm{BCh}$ was monitored by following the formation of the yellow 5-thio-2-nitrobenzoate anion at $412 \mathrm{~nm}$ for $15 \mathrm{~min}$, which resulted from the reaction of DTNB with thiocholine, released by the enzymatic hydrolysis of either $\mathrm{ACh}$ or $\mathrm{BCh}$, respectively. All reactions were performed in triplicate and recorded in 96-well microplates, using VERSA max (Molecular Devices, Sunnyvale, CA, U.S.A.). Percent inhibition was calculated from $(1-\mathrm{S} / \mathrm{E}) \times$ 100, where $\mathrm{E}$ and $\mathrm{S}$ were the respective enzyme activities without and with the tested sample, respectively. The ChEs inhibitory activity of each sample was expressed in terms of the $\mathrm{IC}_{50}$ value $(\mu \mathrm{M}$ required to inhibit the hydrolysis of the substrate, $\mathrm{ACh}$ or $\mathrm{BCh}$, by $50 \%$ ), as calculated from the logdose inhibition curve.

Kinetic Parameters of $\mathbf{1 - 3}$ and 5 in $\mathrm{AChE}$ Inhibition In order to determine the inhibition mechanism, AChE inhibition was evaluated by monitoring the effects of different concentrations of substrates $(0.6,0.3$, and $0.1 \mathrm{~mm}$ for $\mathbf{1}, \mathbf{3}$, and 5; 0.6, 0.4, and $0.2 \mathrm{~mm}$ for 2 ), respectively. The reaction mixture consisted of the aforementioned ChEs assay method:

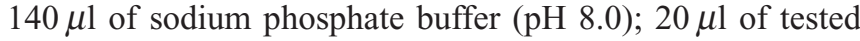
sample solution (f.c. $100 \mu \mathrm{M}$ for the compounds); $20 \mu \mathrm{l}$ of either AChE solution, mixed and incubated for $15 \mathrm{~min}$ at room temperature. The reactions were initiated upon addition of $10 \mu \mathrm{l}$ of DTNB and $10 \mu \mathrm{l}$ of either ACh. All tested samples and the positive control (galanthamine) were dissolved in $10 \%$ analytical grade DMSO. Inhibition constants $\left(K_{\mathrm{i}}\right)$ were determined by interpretation of the Dixon plot, where the value of the $x$-axis implies $-K_{\mathrm{i}}{ }^{42}$ )

In Vitro BACE1 Enzyme Assay The assay was carried out according to the supplied manual with select modifications. Briefly, a reaction solution which consists of $10 \mu \mathrm{l}$ of assay buffer (50 mm sodium acetate, $\mathrm{pH} 4.5), 10 \mu \mathrm{l}$ of BACE1 $(1.0 \mathrm{U} / \mathrm{ml}), 10 \mu \mathrm{l}$ of the substrate $(750 \mathrm{~nm}$ Rh-EVNLDAEFK-Quencher in $50 \mathrm{~mm}$, ammonium bicarbonate), and $10 \mu \mathrm{l}$ of the tested samples (f.c. $100 \mu \mathrm{M}$ for compounds) dissolved in $10 \%$ DMSO was incubated for $60 \mathrm{~min}$ at $25^{\circ} \mathrm{C}$ in the dark. The proteolysis of two fluorophores (Rh-EVNLDAEFK-Quencher) by BACE1 was monitored by the formation of the fluorescent donor (Rh-EVNL), which increases in fluorescence wavelengths at $530-545 \mathrm{~nm}$ (excitation) and $570-590 \mathrm{~nm}$ (emission), respectively. Fluorescence was measured with a microplate spectrofluorometer (Spectralmax Gemini XPS, Molecular devices, Sunnyvale, CA, U.S.A.). The mixture was irradiated at $545 \mathrm{~nm}$ and the emission intensity was recorded at $585 \mathrm{~nm}$. Percent inhibition (\%) was obtained by the following equation: $\%$ inhibition $=\left[1-\left(\mathrm{S}_{60}-\right.\right.$ $\left.\left.\mathrm{S}_{0}\right) /\left(\mathrm{C}_{60}-\mathrm{C}_{0}\right)\right] \times 100$, where $\mathrm{C}_{60}$ was the fluorescence of the control (enzyme, buffer, substrate) after $60 \mathrm{~min}$ of incubation, $\mathrm{C}_{0}$ was the initial fluorescence of the control, $\mathrm{S}_{60}$ was the fluorescence of the tested samples (enzyme, sample solution, substrate) after $60 \mathrm{~min}$ of incubation, and $\mathrm{S}_{0}$ was the initial fluorescence of the tested samples. To allow for the quenching effect of the samples, the sample solution was added to reaction mixture $\mathrm{C}$, and any reduction in fluorescence by the sample was then investigated. The BACE1 inhibitory activity of each sample was expressed in terms of the $\mathrm{IC}_{50}$ value $(\mu \mathrm{M}$ required to inhibit the proteolysis of the substrate; BACE1, by $50 \%$ ), as calculated from the log-dose inhibition curve. Quercetin was used as a positive control.

Statistics The Kruskal-Wallis test and the Mann-Whitney $U$ test were used to determine the statistical significance of differences between values for various experimental and control groups. Data were expressed as the mean \pm S.E.M. in triplicate.

\section{RESULTS AND DISCUSSION}

Recently, the rhizome and semen of $N$. nucifera have been reported to possess enhancing effects on memory and learning $^{19)}$ and anti-amnesic effects in rats with scopolamineinduced dementia, respectively. ${ }^{25)}$ To the best of the author's knowledge, $N$. nucifera stamens have yet to be studied in the context of anti-AD activity. In addition, phytochemical researches on polar fractions such as $n-\mathrm{BuOH}$ are limited. Therefore, focus was upon characterization of other intriguing components from the $N$. nucifera stamens, with antiAlzheimer effects evaluated via $\mathrm{AChE}, \mathrm{BChE}$, and BACE1 inhibitory assays.

Likewise, a previous study revealed that the rhizome and semens of $N$. nucifera showed AChE inhibition. ${ }^{19,25,43)}$ In this lab's preliminary study, the $\mathrm{MeOH}$ extract of $N$. nucifera stamens exerted good $\mathrm{ChEs}$ inhibition: $\mathrm{IC}_{50}$ values of $40.81 \mu \mathrm{g} / \mathrm{ml}$ for AChE; $61.61 \mu \mathrm{g} / \mathrm{ml}$ for BChE. Thus, bioactive-guided fractionation of the extract was performed to obtain the $\mathrm{CH}_{2} \mathrm{Cl}_{2}$, EtOAc, $n$ - $\mathrm{BuOH}$, and $\mathrm{H}_{2} \mathrm{O}$ fractions. Although all bioactive data were not shown, the EtOAc and $n$ $\mathrm{BuOH}$ fractions exhibited slightly higher $\mathrm{AChE}$ inhibitory activities over other fractions, with respective $\mathrm{IC}_{50}$ values of 33.58 and $24.73 \mu \mathrm{g} / \mathrm{ml}$. Since the EtOAc fraction was reported to contain numerous flavonoids, ${ }^{26,27)}$ and it is well known that these flavonoids might attribute to their ChEs inhibition, ${ }^{44,45)}$ detailed phytochemical investigations and 
anti-AD studies on the $n$-BuOH fraction were carried out; the $n$ - $\mathrm{BuOH}$ fraction also harbors $\mathrm{AChE}$ activities and lacks substantial research.

Repeated column chromatography of the $n$ - $\mathrm{BuOH}$ fraction was accomplished to yield a new $\beta$-cyclogeraniol diglycoside (5), along with four known components $\mathbf{1}-\mathbf{4}$ (Fig. 1). Through comparison of published NMR and EI-MS data, the structures of the known compounds were identified as cycloartenol (1) ${ }^{35,36)} p$-hydroxybenzoic acid (2), ${ }^{37)}$ vanilloloside (3), ${ }^{38)}$ and $5^{\prime}$-O-methyladenosine (4). ${ }^{39)}$ This is the first report of isolation of these four, known compounds $1-4$ from this plant.

Compound $\mathbf{5}$ was obtained as a white amorphous powder. The positive HR FAB-MS of $\mathbf{5}$ afforded a quasi-molecular ion peak at $\mathrm{m} / \mathrm{z} 501.2308[\mathrm{M}+\mathrm{Na}]^{+}$, with a molecular formula of $\mathrm{C}_{22} \mathrm{H}_{38} \mathrm{O}_{11}$. The ${ }^{1} \mathrm{H}-\mathrm{NMR}$ spectrum (Table 1) showed signals for: three methylenes at $\delta 1.34,1.47$, and 1.81 (each $2 \mathrm{H}, \mathrm{m})$; a hydroxymethyl at $\delta 4.85(\mathrm{~d}, J=12.5 \mathrm{~Hz})$ and 4.37

Table 2. Anti-Alzheimer Activities of $\mathbf{1}-\mathbf{5}$ from N. nucifera Stamens

\begin{tabular}{ccccc}
\hline \hline Compounds & $\mathrm{AChE}^{a)}$ & $\mathrm{BChE}^{b)}$ & $\mathrm{SI}^{c)}$ & $\mathrm{BACE}^{d}{ }^{d}$ \\
\hline $\mathbf{1}$ & $11.89 \pm 1.91$ & $13.93 \pm 1.65$ & 1.2 & $>100$ \\
$\mathbf{2}$ & $20.07 \pm 0.07$ & $62.29 \pm 1.18$ & 3.1 & $>100$ \\
$\mathbf{3}$ & $4.55 \pm 0.72$ & $205.78 \pm 0.79$ & 45.7 & $>100$ \\
$\mathbf{4}$ & $>100$ & $>100$ & - & $>100$ \\
$\mathbf{5}$ & $3.20 \pm 0.22$ & $83.06 \pm 0.80$ & 26.0 & $>100$ \\
Galanthamine $^{e)}$ & $0.02 \pm 0.00$ & $0.87 \pm 0.07$ & & \\
Quercetin $^{f)}$ & & & & $7.15 \pm 0.45$
\end{tabular}

$a), b), d)$ Final concentrations of test samples were $100 \mu \mathrm{M}$ for test compounds, dissolved in $10 \%$ DMSO; $50 \%$ inhibition concentrations $\left(\mathrm{IC}_{50}, \mu \mathrm{M}\right)$ are expressed as the mean \pm S.E.M. of triple experiments. c) SI: selectivity index (BChE/AChE). e) Galanthamine and $f$ ) quercetin were reference compounds in the ChEs and BACE1 assays. (dd, $J=12.5,5.2 \mathrm{~Hz}$ ); three tertiary methyls at $\delta 1.11,1.12$, and 1.77 (each $3 \mathrm{H}, \mathrm{s}$ ), assigned to a $\beta$-cyclogeraniol. ${ }^{46)}$ This observation was further confirmed by ${ }^{13} \mathrm{C}$-NMR spectrometric assignments (Table 1), coupled with the DEPT and heteronuclear multiple quantum correlation (HMQC) spectral data: two olefinic carbons at $\delta 134.3$ and 134.5; one hydroxymethyl carbon at $\delta 70.2$; three methyl carbons at $\delta 28.6$, 28.7, and 20.2; three hydrocarbons at $\delta$ 19.6, 32.9, and 39.6; one quaternary carbon at $\delta 34.2$. The respective heteronuclear multiple bond connectivity (HMBC) correlations of $\delta_{\mathrm{H}}$ $1.81(\mathrm{H}-3)$ and $\delta_{\mathrm{H}} 1.12(\mathrm{H}-7)$ to $\delta_{\mathrm{C}} 134.3(\mathrm{C}-2) / 134.5(\mathrm{C}-1)$ were observed. The hydroxymethyl group could be located at $\mathrm{C}-1$ due to correlation between the signals of $\delta_{\mathrm{H}} 4.85 / 4.37$ $(\mathrm{H}-9)$ and $\delta_{\mathrm{C}} 134.3(\mathrm{C}-2) / 134.5(\mathrm{C}-1) / 34.2$ (C-6) in the $\mathrm{HMBC}$ spectrum. In addition, the ${ }^{1} \mathrm{H}-{ }^{1} \mathrm{H}$ correlation spectroscopy (COSY) spectrum of $\mathbf{5}$ showed that the H-3 signal ( $\delta$ 1.81) was coupled with the H-4 $(\delta 1.47)$, and in turn the $\mathrm{H}-4$ signal was coupled with the H-5 ( $\delta$ 1.34), indicating a three-methylene spin system in close proximity. However, the ${ }^{1} \mathrm{H}-\mathrm{NMR}$ contained signals for two anomeric protons at $\delta$ 5.17 and 4.75, and twelve oxygenated protons due to two hexose units, in combination with the ${ }^{13} \mathrm{C}-\mathrm{NMR}$ spectrum. Upon acid hydrolysis, 5 yielded monosaccharide units identified by co-TLC (EtOAc-MeOH-H $\left.{ }_{2} \mathrm{O}-\mathrm{AcOH}, 65: 20: 15: 15\right)$ with an authentic sample (glucose). The absolute configuration was determined as D-glucose by GC analysis. ${ }^{47)}$ The configurations of the glycosidic linkages for the glucopyranoside units were determined as the $\beta$ form on the basis of the $J_{1,2}$ values of the anomeric protons of $7.8 \mathrm{~Hz}(\delta 5.17)$ and $7.8 \mathrm{~Hz}$ $(\delta$ 4.75). Sugar connectivity was determined on the basis of correlations between the $\delta_{\mathrm{H}} 4.75\left(\mathrm{H}-1^{\prime}\right)$ and $\delta_{\mathrm{C}} 70.2(\mathrm{C}$ 9), and $\delta_{\mathrm{H}} 5.17\left(\mathrm{H}-1^{\prime \prime}\right)$ and $\delta_{\mathrm{C}} 66.0\left(\mathrm{C}-6^{\prime}\right)$, supporting the
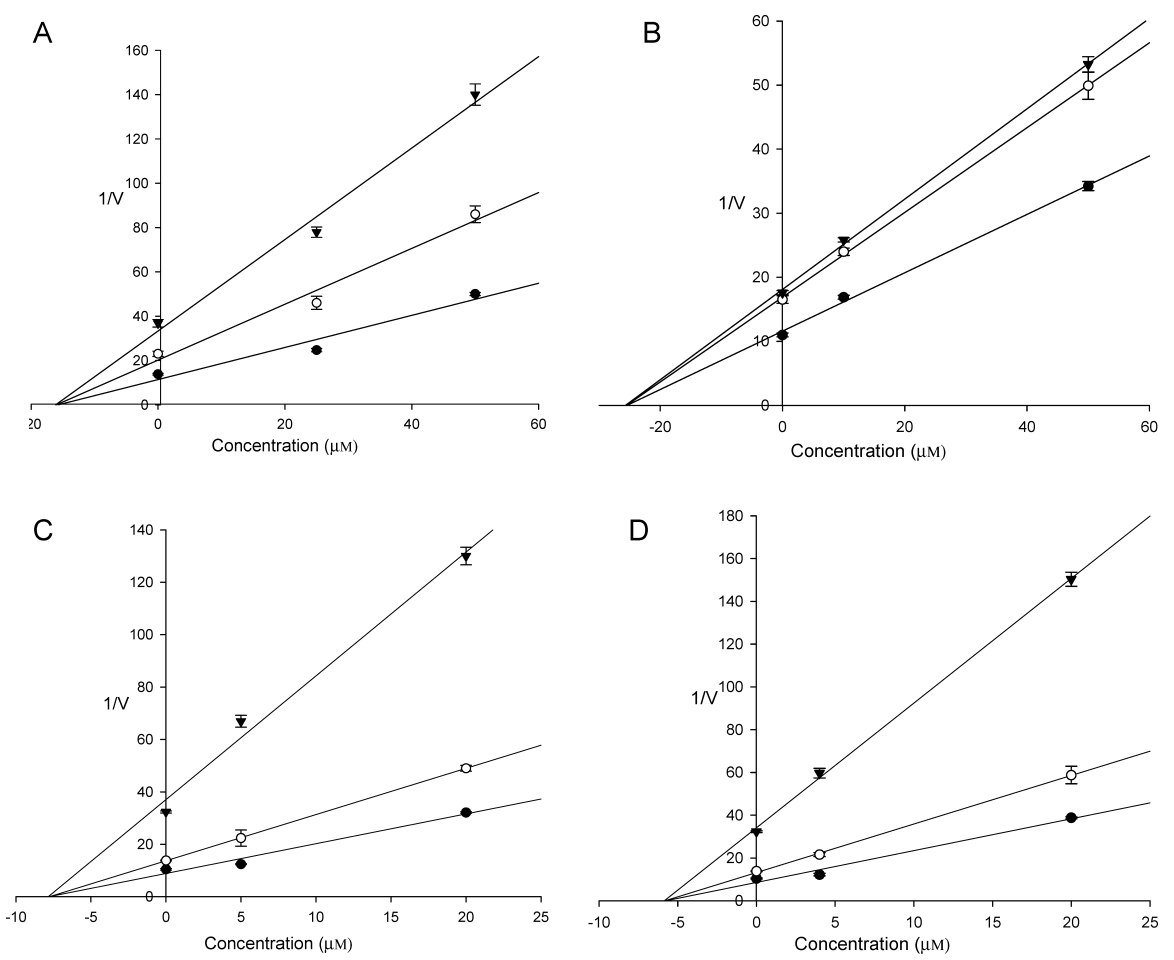

Fig. 2. Dixon Plots for Inhibition of Compounds $\mathbf{1}-\mathbf{3}$, and $\mathbf{5}$ towards AChE in the Presence of Different Concentrations of Substrate

The reaction was performed in the presence of various concentrations of compounds. Results are expressed as means \pm S.E.M. in triplicate. (A) Cycloartenol (1) [0.6 (•), 0.3

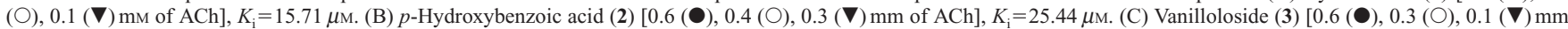
of ACh], $K_{\mathrm{i}}=7.76 \mu \mathrm{M}$. (D) Nuciferoside (5) $\left[0.6(\bullet), 0.3(\bigcirc), 0.1(\mathbf{\nabla}) \mathrm{mm}\right.$ of ACh], $K_{\mathrm{i}}=5.76 \mu \mathrm{M}$. 
presence of a gentiobiose. The structure of $\mathbf{5}$ was thus determined to be a new $\beta$-cyclogeraniol diglycoside [1-hydroxymethyl-2,6,6-trimethyl-1-cyclohexene 9- $O$ - $\beta$-D-glucopyranosyl-( $1 \rightarrow 6)-\beta$-D-glucopyranoside], and named nuciferoside.

The anti-Alzheimer effects of $\mathbf{1}-\mathbf{5}$ from $N$. nucifera stamens were evaluated via the $\mathrm{AChE}, \mathrm{BChE}$, and BACE1 inhibition assays. As shown in Table 2, 1-3 and $\mathbf{5}$ exhibited good AChE inhibitory activities with $\mathrm{IC}_{50}$ values of 11.89 , $20.07,4.55$, and $3.20 \mu \mathrm{M}$, respectively, as compared with a positive control, galanthamine $\left(\mathrm{IC}_{50}=0.02 \mu \mathrm{M}\right)$. In the $\mathrm{BChE}$ inhibitory assay, $\mathbf{1}, \mathbf{2}$, and $\mathbf{5}$ exhibited inhibitory activities with $\mathrm{IC}_{50}$ values of $13.93,62.29$, and $83.06 \mu \mathrm{M}$, as compared with galanthamine $\left(\mathrm{IC}_{50}=0.87 \mu \mathrm{M}\right)$. The selectivity index (SI) values of $\mathbf{1}, \mathbf{2}, \mathbf{3}$, and $\mathbf{5}$, calculated from $\mathrm{IC}_{50}$ values of BChE and AChE, were 1.2, 3.1, 45.7 and 26.0 (Table 2). Although some research has been performed on ChEs inhibitory activities of monoterpenes ${ }^{48-50}$ ) and tetracyclic steroidal alkaloids, ${ }^{51,52)}$ this is the first reports on the ChEs inhibitory activities of $\mathbf{1}-\mathbf{3}$ and $\mathbf{5}$.

In order to determine the type of AChE inhibition, kinetic analysis of $\mathbf{1}-\mathbf{3}$ and $\mathbf{5}$ was carried out by monitoring the effects of three different concentrations of $\mathrm{ACh}$ as a substrate (0.6, 0.3, and $0.1 \mathrm{~mm}$ for 1, 3, and 5; $0.6,0.4$ and $0.2 \mathrm{~mm}$ for 2) by Dixon plots. As demonstrated in Figs. $2 \mathrm{~A}-2 \mathrm{D}$, the manner of inhibition of $\mathbf{1}-\mathbf{3}$ and $\mathbf{5}$ was noncompetitive with $K_{\mathrm{i}}$ values of $15.71,25.44,7.76$, and $5.76 \mu \mathrm{M}$, respectively, as compared with a competitive inhibitor, galanthamine. ${ }^{53)}$ However, $\mathbf{1}-\mathbf{5}$ showed no BACE1 inhibition up to $100 \mu \mathrm{M}$.

In conclusion, a new $\beta$-cyclogeraniol diglycoside, nuciferoside (5), along with four known compounds, cycloartenol (1), $p$-hydroxybenzoic acid (2), vanilloloside (3), and 5'-Omethyladenosine (4), were isolated from the $n$-BuOH fraction of $N$. nucifera stamens for the first time. To further delineate their potential regarding prevention and treatment of $\mathrm{AD}, \mathrm{AChE}, \mathrm{BChE}$, and BACE1 inhibition assays were carried out. As a result, $\mathbf{1}-\mathbf{3}$ and $\mathbf{5}$ showed good and noncompetitive AChE inhibitory activities while 1, 2, and $\mathbf{5}$ exhibited $\mathrm{BChE}$ inhibitory activities. According to the ChEs assay results, the authors contend that $\mathbf{1}-\mathbf{3}$ and $\mathbf{5}$ are possible ChEs inhibitors with potential for treatment of AD. Therefore, $N$. nucifera stamens-derived compounds could potentially exert their anti-Alzheimer effects primarily as AChE inhibitors rather than BACE1 inhibitors.

Acknowledgements This study was supported by the Technology Development Program for Agriculture and Forestry (TDPAF), Ministry of Agriculture and Forestry, Republic of Korea; Pukyong National University under the 2009 Post-Doc. Program; and Blue-Bio Industry RIC at Dongeui University as a RIC program under Ministry of Knowledge Economy and Busan city.

\section{REFERENCES}

1) La Cour B., Mflgaard P., Yi Z., J. Ethnopharmacol., 46, 125-129 (1995).

2) Sridhar K. R., Bhat R., J. Agric. Technol., 3, 143-155 (2007).

3) Kim J. G.., "Illustrated Natural Drugs Encyclopedia," Vol. II, Namsandang, Korea, 1997, p. 95.

4) Cho E. J., Yokozawa T., Rhyu D. Y., Kim S. C., Shibahara N., Park J. C., Phytomedicine, 10, $544-551$ (2003).

5) Wu M. J., Wang L., Weng C. Y., Yen J. H., Am. J. Chin. Med., 31, $687-982$ (2003).
6) Kashiwada Y., Aoshima A., Ikeshiro Y., Chen Y. P., Furukawa H., Itoigawa M., Fujioka T., Misashi K., Cosentino M. L., MorrisNatschke S. L., Lee K. H., Bioorg. Med. Chem., 13, $443-448$ (2005).

7) Ono Y., Hattori E., Fukaya Y., Imai S., Ohizumi Y., J. Ethnopharmacol., 106, 238-244 (2006).

8) Ohkoshi E., Miyazaki H., Shindo K., Watanabe H., Yoshida A., Yajima H., Planta Med., 73, 1255-1259 (2007).

9) Lin M. C., Kao S. H., Chung P. J., Chan K. C., Yang M. Y., Wang C. J., J. Agric. Food Chem., 57, 5925-5932 (2009).

10) Mukherjee P. K., Balasubramanian R., Saha K., Pal M., Saha B. P., Indian Drugs, 32, 274-276 (1995).

11) Mukherjee P. K., Das J., Balasubramanian R., Saha K., Pal M., Saha B. P., Indian J. Pharm., 27, 262-364 (1995).

12) Mukherjee P. K., Das J., Saha K., Pal M., Saha B. P., Phytother. Res., 10, $424-425$ (1996).

13) Mukherjee P. K., Giri S. N., Saha K., Pal M., Saha B. P., Indian J. Microbiol., 35, 327-330 (1995).

14) Mukherjee P. K., Das J., Saha K., Giri S. N., Pal M., Saha B. P., Indian J. Exp. Biol., 34, 275-276 (1996).

15) Mukherjee P. K., Saha K., Das J., Pal M., Saha B. P., Planta Med., 63, 367-369 (1997).

16) Mukherjee P. K., Pal S. R., Saha K., Saha B. P., Phytother. Res., 9, 522-524 (1995).

17) Mukherjee P. K., Saha K., Pal M., Saha B. P., J. Ethnopharmacol., 58, 207-213 (1997).

18) Shoji N., Umeyama H., Saito N., Iuchi A., Takemoto T., Kajiwara A., Ohizumi Y., J. Nat. Prod., 50, 773 -774 (1987).

19) Yang W. M., Shim K. J., Choi M. J., Park S. Y., Choi B. J., Chang M. S., Park S. K., Neurosci. Lett., 443,104-107 (2008).

20) Sohn D. H., Kim Y. C., Oh S. H., Park E. J., Li X., Lee B. H., Phytomedicine, 10, 165-169 (2003).

21) Rai S., Wahile A., Mukherjee K., Saha B. P., Mukherjee P. K., J. Ethnopharmacol., 104, 322-337 (2006).

22) Mazumder U. K., Gupta M., Pramanik G., Mukhopadhyay R. K., Sarkar S., Indian J. Exp. Biol., 30, 533-534 (1992).

23) Xin L. Z., "The Pharmacology of Chinese Herbs," ed. by Huang K. C., CRC Press Inc., U.S.A., 1999, p. 192.

24) Xiao J. H., Zhang J. H., Chen H. L., Feng X. L., Wang J. L., Planta Med., 71, 225-305 (2005).

25) Oh J. H., Choi B. J., Chang M. S., Park S. K., Neurosci. Lett., 461, $41-44$ (2009).

26) Jung H. A., Kim J. E., Chung H. Y., Choi J. S., Arch. Pharm. Res., 26, $279-285$ (2003).

27) Hyun S. K., Jung Y. J., Chung H. Y., Jung H. A., Choi J. S., Arch. Pharm. Res., 29, 287-292 (2006).

28) Lim S. S., Jung Y. J., Hyun S. K., Lee Y. S., Choi J. S., Phytother. Res., 20, 825-830 (2006).

29) Shim S. Y., Choi J. S., Byun D. S., J. Microbiol. Biotechnol., 19, 155 602 (2009)

30) Scarpini E., Scheltens P., Feldman H., Lancet Neurol., 2, 539-547 (2003).

31) Parihar M. S., Hemnani T., J. Clin. Neurosci., 11, 456-467 (2004).

32) Rao A. A., Sridhar G. R., Das U. N., Med. Hypotheses, 69, 1272 1276 (2007).

33) Vassar R., Adv. Drug Deliv. Rev., 54, 1589-1602 (2002).

34) Yan R., Bienkowski M. J., Shuck M. E., Miao H., Tory M. C., Pauley A. M., Brashier J. R., Stratman N. C., Mathews W. R., Buhl A. E., Carter D. B., Tomasselli A. G., Parodi L. A., Heinrikson R. L., Gurney M. E., Nature (London), 402, 533-537 (1999).

35) Nes W. D., Norton R. A., Crumley F. G., Madigan S. J., Katz E. R., Proc. Natl. Acad. Sci. U.S.A., 87, $7565-7569$ (1990).

36) Goad L. J., Akihisa T., "Anaylsis of Sterol," 1st ed., Chapman \& Hall, U. K., 1997, p. 403.

37) Ida Y., Satoh Y., Ohtsuka M., Nagasao M., Shoji J., Phytochemistry, 35, 209-215 (1993).

38) Tan J., Bednarek P., Liu J., Schneider B., Svatos A., Hahlbrock K., Phytochemistry, 65, 691-699 (2004).

39) van Tilburg E. W., van der Klein P. A., von Frijtag Drabbe Künzel J., de Groote M., Stannek C., Lorenzen A., IJzerman A. P., J. Med. Chem., 44, 2966-2975 (2001).

40) Hara S., Okabe H., Mihashi K., Chem. Pharm. Bull., 34, 1843-1845 (1986).

41) Ellman G. L., Courtney K. D., Andres V. Jr., Featherstone R. M., Biochem. Pharmacol., 7, 88-95 (1961). 
42) Cornish-Bowden A., Biochem. J., 137, 143-144 (1974).

43) Mukherjee P. K., Kumar V., Houghton P. J., Phytother. Res., 21, $1142-1145$ (2007).

44) Jung M., Park M., Molecules, 12, 2130-2139 (2007).

45) Conforti F., Rigano D., Menichini F., Loizzo M. R., Senatore F., Fitoterapia, 80, 62-67 (2009).

46) Okazaki R., Kiyota H., Oritani T., Biosci. Biotechnol. Biochem., 64, 1444-1447 (2000).

47) Min B. S., Nakamura N., Miyashiro H., Kim Y. H., Hattori M., Chem. Pharm. Bull., 48, 194-200 (2000).

48) Keane S., Ryan M. F., Insect Biochem. Mol. Biol., 29, 1097-1104
(1999).

49) Perry N. S., Bollen C., Perry E. K., Ballard C., Pharmacol. Biochem. Behav. 75, 651-659 (2003).

50) Miyazawa M., Watanabe H., Kameoka H., J. Agric. Food Chem., 45, $677-679$ (1997).

51) Sauvaître T., Barlier M., Herlem D., Gresh N., Chiaroni A., Guenard D., Guillou C., J. Med. Chem., 50, 5311-5323 (2007).

52) Choudhary M. I., Shahnaz S., Parveen S., Khalid A., Mesaik M. A., Ayatollahi S. A., Atta-ur-Rahman, Chem. Biodivers., 3, 1039-1052 (2006).

53) Harvey A. L., Pharmacol. Ther, 68, 113-128 (1995). 